The Chemosensitizing Effect of Portulaca oleracea Methanol Extract on Human Colorectal and Lung Cancer Cells Against Irinotecan

\author{
Mehmet Kadir ERDOĞAN \\ Department of Molecular Biology and Genetics, Faculty of Arts and Sciences, Bingol University, 12000, Bingol, Turkey \\ 1https://orcid.org/0000-0002-1579-5737 \\ $\bowtie$ : mkerdogan@bingol.edu.tr
}

\begin{abstract}
Cancer is a major health problem causing great damage in recent years worldwide. Serious side effects of chemotherapeutics used in cancer treatment make natural products valuable. Combined use of chemotherapy drugs and herbal products is an important approach in reducing side effects and revealing a more effective treatment. In this study, the effects of methanolic extract from Portulaca oleracea (POM) alone and in combination with irinotecan were investigated against human colorectal carcinoma cell line HCT116 and human lung adenocarcinoma cell line A549. The antiproliferative/anti-colony formation effects were determined using WST-1 assay and clonogenic assay. Cell death detection enzyme-linked immunosorbent assay (ELISA) was employed to exhibit the triggered apoptosis, and quantitative real time polimerase chain reaction (qRT-PCR) was performed to evaluate the mRNA expression of mTOR, Akt and PTEN genes, which are significant modulators of apoptotic and survival pathways. It was determined that $72 \mathrm{~h}$ treatment with increasing concentrations of POM $(0-1000 \mu \mathrm{g} \mathrm{mL}-1)$ decreased the viability of HCT116 and A549 cells in a dose-dependent manner. Also, POM and irinotecan exhibited synergistic effects in both cell lines. The combination of POM and irinotecan suppressed the colony forming capacity of HCT116 and A549 cells by $84 \%$ and $79 \%$, respectively. POM also altered mTOR, Akt and PTEN gene expressions in HCT116 and A549 carcinoma cells, both alone and in combination with irinotecan. This study indicates that the phytotherapeutic effect of $P$. oleracea needs to be studied more intensively.
\end{abstract}

\section{Portulaca oleracea Metanol Ekstraktının İnsan Kolorektal ve Akciğer Kanseri Hücrelerini Irinotekana} Karşı Kemosensitize Edici Etkisi

\section{ÖZET}

Kanser önemli bir sağlık sorunudur ve son yıllarda dünya çapında büyük zararlara neden olmaktadır. Kanser tedavisinde kullanılan kemoterapötiklerin ciddi yan etkileri, doğal ürünleri değerli kılmaktadır. Kemoterapi ilaçları ile bitkisel ürünlerin birlikte kullanılması, yan etkilerin azaltılması ve daha etkili bir tedavinin ortaya çıkarılmasında önemli bir yaklaşımdır. Bu çalışmada, tek başına ve irinotekan ile kombinasyon halinde Portulaca oleracea metanol ekstraktının (POM) etkileri, insan kolorektal karsinoma hücre hattı HCT116 ve insan akciğer adenokarsinom hücre hattı A549'a karşı araştırılmıştır. Antiproliferatif / anti-koloni oluşumu etkileri, WST-1 deneyi ve koloni oluşumu deneyi ile belirlendi. Hücre ölümü tespiti enzim bağll immunosorbent analizi (ELISA) tetiklenen apoptozu göstermek için kullanıldı, ve apoptotik ve hayatta kalma yolaklarının önemli modülatörleri olan mTOR, Akt ve PTEN genlerinin mRNA ekspresyonunu değerlendirmek için kantitatif gerçek zamanlı polimeraz zincir reaksiyonu (qRT-PCR) gerçekleştirildi. Artan POM konsantrasyonları (0-1000 $\left.\mu \mathrm{g} \mathrm{mL} \mathrm{m}^{-1}\right)$ ile 72 saatlik tedavinin doza bağlı olarak HCT116 ve A549 hücrelerinin

\section{Research Article}

$\begin{array}{ll}\text { Article History } & \\ \text { Received } & : 06.01 .2021 \\ \text { Accepted } & : 01.04 .2021\end{array}$

Keywords

Portulaca oleracea

Irinotecan

Cancer

Apoptosis

Cell culture

Anahtar Kelimeler
Portulaca oleracea
İinotekan
Kanser
Apoptoz
Hücre kültürü

Makale Tarihçesi
Geliş Tarihi $\quad: 06.01 .2021$
Kabul Tarihi $\quad: 01.04 .2021$


canlılığını azalttığı belirlendi. Ayrıca, POM ve irinotekan, her iki hücre hattında da sinerjik etkiler sergiledi. POM ve irinotekan kombinasyonu, HCT116 ve A549 hücrelerinin koloni oluşturma kapasitesini sırasıyla \%84 ve \%79 oranında baskıladı. POM ayrıca HCT116 ve A549 karsinom hücrelerinde mTOR, Akt ve PTEN gen ekspresyonlarını hem tek başına hem de irinotekan ile kombinasyon halinde değiştirdi. Bu çalışma, P. oleracea'nın fitoterapötik etkisinin daha yoğun olarak araştırılması gerektiğini göstermektedir.

To Cite : Erdoğan MK 2021. The Chemosensitizing Effect of Portulaca oleracea Methanol Extract on Human Colorectal and Lung Cancer Cells Against Irinotecan. KSU J. Agric Nat 24 (6): 1187-1195. DOI: 10.18016/ksutarimdoga.vi.848187.

\section{INTRODUCTION}

Cancer is a heterogeneous disease that characterized by uncontrolled proliferation, subsequent cellular transformation, angiogenesis, invasion and metastasis. The incidence and mortality of cancer is increasing year by year, and this rise reinforces the cancer remains one of the most devastating health problem. Lung cancer ranks first in the world in terms of incidence and mortality among cancers, and colorectal cancer is the second cause of cancer related deaths and is the fourth most common type of cancer worldwide (Bray et al., 2018). In cancer treatment the most commonly used applications are surgery, radiotherapy and chemotherapy. However, reasons such as recurrence of the tumor as a result of surgical intervention or the serious side effects of the drugs used in chemotherapy requires the development of safer and more effective approaches for cancer treatments (Afolayan et al., 2020). Recently, the complementary and alternative use of plants in cancer treatment has attracted considerable attention (Majolo et al., 2019; Younes et al., 2020).

Plants have been used therapeutically as well as many usage areas since ancient times and are an important resource at the point where modern medicine comes. It is known that the drug used in the treatment of most diseases is developed by taking inspiration from plants. An important part of chemotherapeutic drugs used especially in cancer treatment are derivatives of the compounds isolated from medicinal plants. The anticancer effect of plants can play crucial roles in the prevention and treatment of cancer, which is a major health problem for the most communities (Borah and Banik, 2020; Erdogan et al., 2020a).

Portulaca oleracea (purslane) is an annual edible green leafy vegetable that widespreads in many regions of Europe, Asia, Africa, and the Middle East. It widely consumed as a potherb added in soups and salads. In many countries purslane used as a herbal medicine in the treatment of headaches, pain and swelling, intestinal and stomach illnesses, and shortness of breath (Nemzer et al., 2020). Omega-3 fatty acids, quercetin, kaempferol, apigenin, vitamin $\mathrm{A}$ and $\mathrm{C}$, and tocopherols are among the main components of $P$. oleracea that makes purslane beneficial for health (Lim and Quah, 2007). Many pharmacological effects of this plant was reported, including antiinflammatory, cardiac stimulant, antioxidative, wound-healing, antibacterial, and anti-tumor (Xiang et al., 2005).

Apoptosis is a programmed or physiological form of cell death that occurs within genetic control by activating endogenous proteases in the cell. As a result of this process, the cell shrinks, the structure of the cytoskeleton is distorted, and membrane bubbling occurs, as well as nuclear condensation and nucleosomal DNA fragmentation. Since the cell's orientation to apoptosis occurs with the control of genes, mutations in these genes can lead to apoptosis avoidance (Ferreira et al., 2002).

Irinotecan is a camptothecin derivative that used in various cancer types including colorectal, prostate, pancreatic, and lung cancer as a chemotherapy agent. Although irinotecan is one of the essential medicines used in cancer treatment, it causes common side effects, including colon inflammation, fever, bone marrow, blood clots, shortness of breath, vomiting and diarrhea (Huang et al., 2020). Therefore, the development of new adjuvant treatment approaches that can reduce the side effects and increase anticancer efficacy of irinotecan even at low doses can make important contributions to cancer treatment. This study focused on the mechanistic elucidation of the possible interaction between POM and irinotecan in inhibiting the proliferation and inducing apoptosis of colon and lung cancer cells. In addition, the study aims to investigate the regulation of genes involved in various pathways related to survival and apoptosis in colon and lung cancer cells treated with POM and / or irinotecan.

\section{MATERIALS and METHOD}

\section{Chemicals and Reagents}

The fetal bovine serum (FBS), penicillin/streptomycin, Dulbecco's modified eagle medium (DMEM), and phosphate buffered saline (PBS) was purchased from Lonza (Walkersville, MD, USA). Trypan blue, trypsinEDTA, methanol, acetic acid and crystal violet was obtained from Sigma-Aldrich (St. Louis, MO, USA). Water Soluble Tetrazolium-1; 2-(4-Iodophenyl)-3-(4nitrophenyl)-5-(2, 4-disulfophenyl)-2H-tetrazolium, 
monosodium salt (WST-1) cell proliferation assay kit was procured from Intron Biotechnology (Gyeonggi-do, Korea). Cell death detection ELISA kit was purchased from Roche (Mannheim, Germany). Irinotecan was procured from Kocak Pharma (Istanbul, Turkey). Forward and reverse primers were obtained from Invitrogen (Carlsbad, CA, USA), pure link RNA mini kit from Life Technologies (Carlsbad, CA, USA), 2xqPCRBIO SyGreen mix Lo-ROX kit from PCR Biosystems (London, UK), and high capacity cDNA reverse transcriptase kit from Thermo Fisher (Waltham, MA, USA), and analysis with kits was performed according to manufacturer's protocols.

\section{Plant Material}

The aerial parts of $P$. oleracea were obtained from a local market from Bingol, Turkey, and the samples were identified by Yakup Yapar from the Department of Biology, Bingol University. The plant samples were thoroughly washed and freed from water via a filter paper. Then, the samples were left to dry in an environment without sunlight and moisture. The dried samples were finely grounded using an blender for extraction. A voucher specimen was deposited in the Herbarium of Faculty of Arts and Sciences, Department of Biology, Bingol University (herbarium No. 6565).

\section{Methanolic Extraction}

Overall, $20 \mathrm{~g}$ of finely powdered plant material was placed to the Whatman no. 1 filter paper and tightly closed. $400 \mathrm{~mL}$ of analytical grade methanol (1:20/w:v) was placed to a flask and Soxhlet apparatus heated to at $50^{\circ} \mathrm{C}$ until getting a clear solvent in extraction chamber. Then the solvents in the mixture, which collected in the bottom flask, were evaporated by a rotary evaporator (IKA Rotary Evaporator model RV10, Werke GmbH Co. KG, Germany) under reduced pressure at $45^{\circ} \mathrm{C}$. Subsequently, the extracts were kept in a vacuum oven at $25^{\circ} \mathrm{C}$ until they became powdered and stored at $-20{ }^{\circ} \mathrm{C}$ (Aizpurua-Olaizola et al., 2015; Erdogan et al., 2019). The powdered extracts were dissolved in traces of methanol and diluted with DMEM for further use in the studies.

\section{Cells and Culture Conditions}

HCT116 human colorectal carcinoma cells and A549 human non-small cell lung cancer cell line were provided by the cell repository of the Central Laboratory Research and Application Center of Bingol University, Turkey. The cell lines were maintained in DMEM with $10 \%$ fetal bovine serum (FBS) and 1\% penicillin-streptomycin, and in a humidified atmosphere by $5 \% \mathrm{CO}_{2}$ and $37^{\circ} \mathrm{C}$ (Erdogan et al., $2020 \mathrm{a}$ ). When the cells reached $80 \%$ of density, they were trypsinized to detach from the bottom surface and were counted in Neubauer's chamber for used in studies.

\section{Cell Viability}

The dose-dependent antiproliferative effects of POM, irinotecan, and combinations were measured by the WST-1 cell proliferation assay kit according to manufacturer`s protocol (Intron Biotechnology, Gyeonggi-do, Korea). Briefly, $5 \times 10^{3}$ cells/well were seeded into 96-well culture plates and incubated at $37^{\circ} \mathrm{C}$ and $5 \% \mathrm{CO}_{2}$ overnight. HCT 116 and $\mathrm{A} 549$ cells were treated with various concentrations of POM (0, $25,50,100,200,400,600,800$ and $\left.1000 \mu \mathrm{g} \mathrm{mL}^{-1}\right)$ and irinotecan $(0,0.59,1.47,2.94,5.88,14.66,29.35$ and $\left.58.70 \mu \mathrm{g} \mathrm{mL}^{-1}\right)$ for $72 \mathrm{~h}$. Culture medium was replaced by fresh medium and $10 \mu \mathrm{L}$ of WST- 1 reagent were pipetted into wells. After $3 \mathrm{~h}$ incubation period, the amount of soluble formazan dye produced by metabolically active cells was measured with an ELISA microplate reader (SpectraMax 384 Plus, Molecular Devices, USA) at $450 \mathrm{~nm}$ as absorbance (optical density-OD). The mixture of WST-1 reagent and culture medium without cells was evaluated as a background control. To determine percentage of cell survival that formula was used:

$\%$ cell survival $=\left[O D_{\text {Treatment }}-\mathrm{OD}_{\text {Blank }} / \mathrm{OD}_{\text {Control }}{ }^{-} \mathrm{OD}_{\text {Blank }}\right]$ $\times 100 \%$.

The absorbance value of the DMEM and WST-1 reagent mixture was evaluated as a blank. The control cells were treated with DMEM and trace methanol mixture only $(1: 50 / \mathrm{v}: \mathrm{v})$. The half maximal inhibitory concentration $\left(\mathrm{IC}_{50}\right)$ value for each treatment group was calculated.

\section{Calculation of Combination Index (CI)}

The combination index of POM and irinotecan treatments was calculated by the following formula $(\mathrm{Li}$ et al., 2017);

$\mathrm{CI}=($ Аром $) 50 /($ Вемм $) 50+($ A Irinotecan $) 50 /($ B Irinotecan $)$ 50 .

In this formula; (АРом) 50: $\mathrm{POM}$ concentration with $50 \%$ inhibition effect when half of the $\mathrm{IC}_{50}$ of irinotecan concentration is applied, (B (A Arinotecan ) 50: Irinotecan concentration with $50 \%$ inhibition effect when half of the $\mathrm{IC}_{50}$ of $\mathrm{POM}$ concentration is applied, (BIrinotecan) 50: $\mathrm{IC}_{50}$ of irinotecan. The CI values found after calculation indicates; CI> 1 antagonism, CI = 1: enhancer and CI $<1$ synergism (Chou and Talalay, 1984).

\section{Colony Formation Assay}

The effect of the treatments on the colony formation capacity of the cells were determined by clonogenic assay which was previously described (Franken et al., 2006). The HCT 116 and A549 cells were seeded in 60 $\mathrm{mm}$ petri dishes $\left(5 \times 10^{2}\right.$ cells/dish) and followed by overnight incubation, the cell lines treated with POM 
(250 $\left.\mu \mathrm{g} \mathrm{mL}^{-1}\right)$, irinotecan $(1.47 \mu \mathrm{g} \mathrm{mL}-1)$ and the combination of $250 \mathrm{\mu g} \mathrm{mL}^{-1} \mathrm{POM}+1.47 \mathrm{\mu g} \mathrm{\textrm {mL } ^ { - 1 }}$ irinotecan for $72 \mathrm{~h}$. After treatment, the medium was sucked off and replaced by fresh medium. The cells were maintained in fresh medium for 12 days, and the formed colonies were fixed with a mixture of methanol : acetic acid $(3: 1 / \mathrm{v}: \mathrm{v})$ for $5 \mathrm{~min}$. Then this mixture was removed, and the petri dishes were washed with cold PBS and stained with crystal violet $(0.05 \%)$ for $15 \mathrm{~min}$. The colony formation were analyzed with the ImageJ 2.1 software and quantitated by GraphPad Prism 8.0.

\section{CDD ELISA}

The cell death detection Elisa (CDDE) method provides in vitro qualitative and quantitative analysis of the histone that passes from the nucleus to cytoplasm due to DNA fragmentation, as a result of apoptotic cell death. Briefly, $1 \times 10^{4}$ cells/well were seeded in 96 well plates and the cells were treated with the half of $\mathrm{IC}_{50}$ doses of POM, irinotecan and the combination of POM+Irinotecan for $72 \mathrm{~h}$. The 96 well plate was centrifuged at $200 \mathrm{xg}$ for $15 \mathrm{~min}$ and after removing the supernatant, $200 \mu \mathrm{L}$ of lysis buffer was added to the wells and incubated at room temperature for $30 \mathrm{~min}$. The lysate was centrifuged at $200 \mathrm{xg}$ for $15 \mathrm{~min}$ and 20 $\mu \mathrm{L}$ of the supernatant was taken and transferred into a streptavidin-coated microplate. $80 \mu \mathrm{L}$ of immunoreagent, that containing anti-histone and antiDNA peroxidase (POD) antibodies, was added to each well. The microplate was covered with a sticky foil and kept on a shaker at a slow speed for $2 \mathrm{~h}$. The liquid part was then removed, the wells were washed with incubation buffer and $100 \mu \mathrm{L}$ of ABTS solution was added to the wells. Then, it was incubated on the microplate shaker for $25 \mathrm{~min}$ to be ready for colorimetric analysis. The absorbance of the wells was measured in the ELISA microplate reader (SpectraMax 384 Plus, Molecular Devices, USA) at 405 $\mathrm{nm}$. In the treatment groups, intense color formation compared to control cells shows the DNA fragmentation characteristic of apoptosis. The absorbances of the groups were divided by the absorbance of the control, and enrichment factors, which are a colorometric indicator of apoptosis, were calculated.

\section{Real-Time Quantitative Polymerase Chain Reaction (qRT-PCR)}

qRT-PCR was performed according to the method previously described (Erdogan et al., 2020b). 1x106 cells were seeded the 6 well microplates and after an overnight incubation, the cells were treated with appropriate treatments (the half of $\mathrm{IC}_{50}$ doses of POM, irinotecan and the combination of POM+Irinotecan) for $72 \mathrm{~h}$. The medium was then removed, $1 \mathrm{~mL}$ of cold PBS was added to the wells and the cells were collected with a scraper. Pure Link RNA Mini kit (Invitrogen-Life
Technologies) for RNA isolation from cells, High Capacity cDNA Reverse Transcriptase Kit (Thermo Fisher) for synthesis of total RNA from composite DNA, SYBR Green master mix for quantitative realtime PCR (2xqPCRBIO SyGreen Mix Lo-ROX Kit, PCR Biosystems) was used and all experimental steps were performed according to the manufacturer's protocols. The PCR reaction conditions were as follows: incubation at $95^{\circ} \mathrm{C}$ for 2 min followed by 40 cycles at $95^{\circ} \mathrm{C}$ for $5 \mathrm{~s}, 64^{\circ} \mathrm{C}$ for $20 \mathrm{~s}, 72^{\circ} \mathrm{C}$ for $2 \mathrm{~min}$, and 1 cycle at $72{ }^{\circ} \mathrm{C}$ for $5 \mathrm{~min}$. A PCR device (Rotor-Gene Q, Qiagen, Hilden, Germany) was used in the analysis. The forward and reverse primer sequences were used as follows: mTOR (forward primer: 5'TGTCCTGCTGGTCTGAACTG-3'; reverse primer: 5'TTCAGCGATGTCTTGTGAGG-3'), Akt (forward primer: 5-'CACACCACCTGACCAAGATG-3'; reverse primer: 5-'CTGGCCGAGTAGGAGAACTG-3'), PTEN (forward primer: 5-'GGTGATGTGGCAGGACTCTT-3'; reverse primer: 5-'CAGCTTCCGAGAGGAGAGAA-3'), and B-actin (forward primer: 5'CTCTTCCAGCCTTCCTTCCT-3'; reverse primer: 5'AGCACTGTGTTGGCGTACAG-3'). mRNA expression rates were determined by the comparative threshold cycle $\left(2^{-\Delta \Delta \mathrm{Ct}}\right)$ method (Livak and Schmittgen, 2001). Ct values were normalized with 6 -actin mRNA expression rates.

\section{Statistical analysis}

Each assay was repeated at least three times and data are given as mean \pm standard deviation (SD). Statistical analysis of the findings were evaluated by one-way ANOVA test using Prism 8.0 (GraphPad Inc., San Diego, CA, USA). P value $<0.05$ was assumed as statistically significant at differences between the groups.

\section{RESULTS and DISCUSSION}

Lung cancer has the highest incidence and mortality among cancer cases worldwide (Bray et al., 2018). Colorectal cancer is the fourth most common cancer type and is the second cause of cancer-related deaths worldwide (Bray et al., 2018), and is an epigeneticbased disorder that causes the colon/rectal mucosa to transform into metastatic carcinoma (Jayathilake et al., 2019). Surgical intervention, radiotherapy, chemotherapy or hormone therapy can be applied in the treatment of lung and colorectal cancer depending on the genetic as well as clinical symptoms. However, the fact that these approaches are responsible for significant side effects necessitates alternative treatment approaches (Younes et al., 2020). Plants and plant derived compounds are considered as important resources in revealing new and alternative treatment approaches in this context. In this study, the viability of A549 human lung cancer and human HCT116 colorectal cancer cells depending on the increasing 
concentration of POM, irinotecan and combination were determined by the WST- 1 cell viability assay and shown in Figure 1a and 1b. Cell viability curves have shown that POM, irinotecan and combination of POM+Irinotecan suppresses proliferation in both cell lines in a dose-dependent manner.

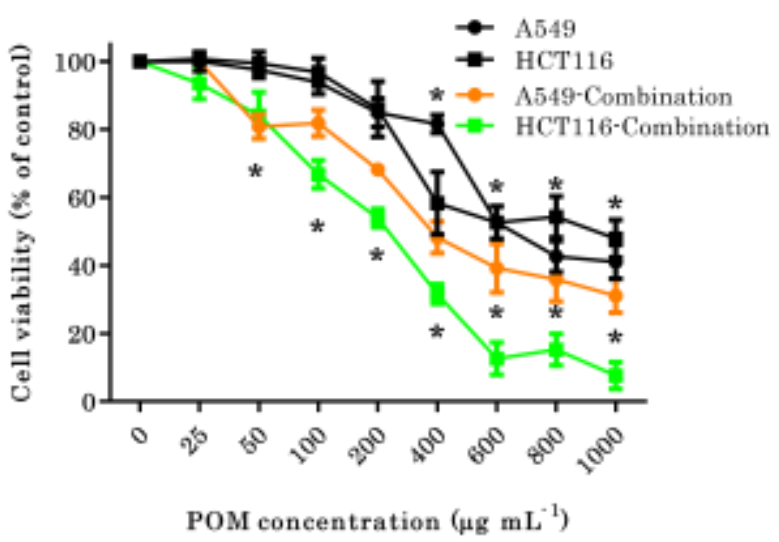

b

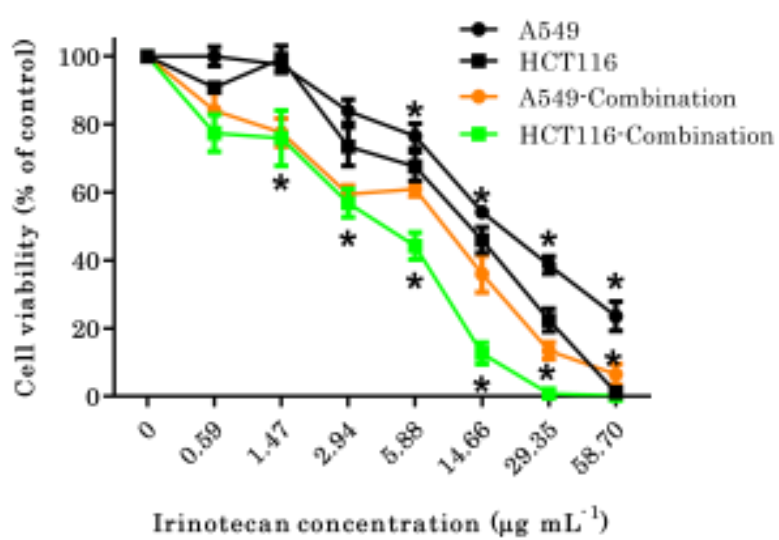

Figure1. The antiproliferative effect of Portulaca oleracea methanol extract and combination of POM+IC $50 / 2$ of irinotecan (a), and irinotecan and combination of Irinotecan+IC $50 / 2$ of POM (b) on HCT116 human colon cancer and A549 human lung cancer cell lines in $72 \mathrm{~h}$ treatment. $\left({ }^{*} \mathrm{P}<0.05\right.$; compared with the untreated cells).

SSekil 1. Portulaca oleracea metanol ekstrakt ile $\mathrm{POM}+$ Irinotekan $\mathrm{IC}_{50} / 2$ kombinasyonunun(a), ve irinotekan ile Irinotekan+ POM IC50/2 kombinasyonunun (b) 72 saatlik tedavide HCT116 insan kolon kanseri ve A549 insan akciğer kanseri hücre hattı üzerindeki antiproliferatif etkisi. (*P<0.05; tedavi edilmeyen hücrelerle karşılaştırıldı̆̆ginda).

Since the 1990s, many large pharmaceutical companies have prioritized investments in combinatorial treatment approaches, which have the potential to increase the effectiveness of treatment processes, as well as studies focusing on natural products (Luzhetskyy et al., 2007; Majolo et al., 2019). Considering the complex nature of the compounds found in plant extracts and the economic and synthetically very difficult to synthesize, the focus has been on the discovery of drugs based on specific molecular targets to obtain more efficient compounds using combinatorial approach technologies (Ojima, 2008; Majolo et al., 2019). It is indicated that combinational approaches will be the future source of numerous new drugs or new chemical entities (Majolo et al., 2019). Of the total of 136 new active substances with cancer-related activity between 1981 and 2014, 113 or $83 \%$ were either directly natural products or developed by imitation of natural products, only 23 or $17 \%$ were of synthetic origin (Newman and Cragg, 2016). Therefore, it has been reportedbwidely that plants have great potential in terms of new therapeutic approaches, and plant-based combinational approaches act mechanically in the processes of cell proliferation, angiogenesis, invasion and apoptosis in the initiation, development and progression of cancer (Rajesh et al., 2015; Majolo et al., 2019). The IC $_{50}$ and CI values obtained by cell viability analysis are presented in Table 1. It is clear from these data that there was a synergistic interaction between POM and irinotecan.

Table 1. The $\mathrm{IC}_{50}$ and combination index values of POM and irinotecan on HCT116 and A549 cells Cizelge 1. POM ve irinotekanın HCT116 ve A549 hücreleri üzerindeki IC 50 ve kombinasyon indeksi değerleri

\begin{tabular}{llcc} 
& & IC 50 values & Combination Index $(\mathrm{CI})$ \\
\hline Cell Line & POM $\left(\mu \mathrm{g} \mathrm{mL}^{-1}\right)$ & Irinotecan $(\mu \mathrm{g} \mathrm{mL}-1)$ & POM+Irinotecan \\
\hline HCT116 & $608.80 \pm 17.32$ & $12.16 \pm 0.77$ & $0.79 \pm 0.03$ \\
A549 & $722.45 \pm 23.19$ & $18.41 \pm 1.24$ & $0.93 \pm 0.04$ \\
\hline
\end{tabular}

Besides being important for the food industry, $P$. oleracea is a pharmacologically valuable plant that exhibits antimicrobial, neuroprotective, antiinflammatory, antioxidant and anticancer activities thanks to its wide range of chemical components such as flavonoids, proteins, alkaloids and vitamins. Although the efficacy of the extracts or compounds obtained from $P$. oleracea has been demonstrated in many in vitro and in vivo studies, the number of studies on their mechanism of action is limited. Therefore, considering $P$. oleracea in advanced clinical 
studies will be possible with more mechanistic studies (Zhou et al., 2015). Al-Sheddi et al. (2015) showed that $P$. oleracea seed oil has been shown to significantly reduce the viability of human liver cancer HepG2 cell line and human lung cancer A549 cells, and the antiproliferative effect of the treatment was higher,

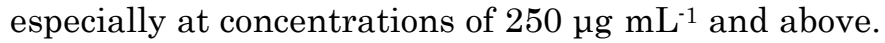
In two previous studies, it was stated that the chloroform extract of the whole plant and aerial parts of $P$. oleracea were exhibited moderate antiproliferative activity in $\mathrm{HCT}-15$ and Caco-2 colon cancer cells, and that the treatment was more effective at higher concentrations (Mali, 2015; El-burai et al., 2020). Similarly, in this study, it was observed that $P$. oleracea methanol extract was exhibited a dosedependent effect on both cancer cell lines, but the antiproliferative activity was further increased especially at high concentrations. This difference may be due to the use of methanol, which has a different polarity, in extraction, and the different geography and climatic conditions where the plant samples were collected (Gecibesler and Erdogan, 2019). A previous study showed that the methanolic extract of $P$. oleracea was non-toxic in normal Chang liver cells and was safe for daily consumption (Payudara et al., 2013). It has also been shown that the hydro-ethanolic extract of $P$. oleracea was not cytotoxic on isolated human lymphocytes (Rahimi et al., 2019). When all these studies are evaluated, it can be concluded that while $P$. oleracea does not exhibit toxic effects on normal cells, it has cytotoxic activity on cancerous cells.

The survival of a single cell and its colony growth can be analyzed by an in vitro colony formation assay or a clonogenic assay method (Franken et al., 2006). As shown in Figure 2, both POM individually and its combination with irinotecan significantly inhibited colony formation of the HCT116 and A549 cells $(\mathrm{P}<0.05)$.

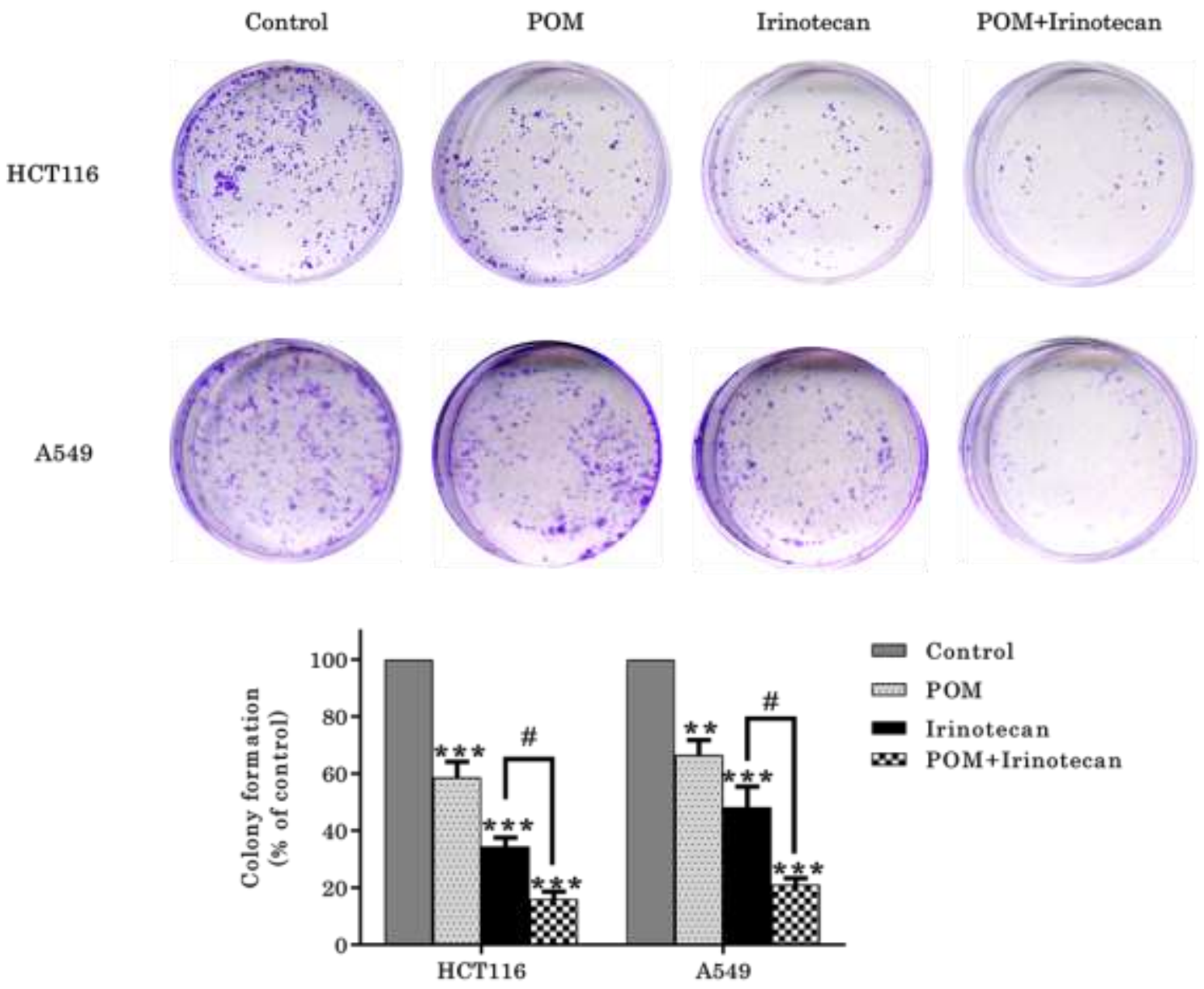

Figure2. Colony formation inhibitory effect of Portulaca oleracea methanol extract and / or irinotecan treatments on HCT116 and A549 cells. $\left({ }^{*} \mathrm{P}<0.05,{ }^{* *} \mathrm{P}<0.01,{ }^{* * *} \mathrm{P}<0.0001\right.$; compared with the untreated cells. ${ }^{*} \mathrm{P}<0.05$; compared with the irinotecan treated cells).

Şekil 2. Portulaca oleracea metanol ekstraktının ve/veya irinotekan tedavilerinin HCT116 ve A549 hücreleri üzerindeki koloni oluşumunu inhibe edici etkisi. ( ${ }^{*} P<0.05,{ }^{* *} P<0.01,{ }^{* * *} P<0.0001$; tedavi edilmeyen hücrelerle karşılaştırıldı̆̆ında. ${ }^{\#} P<0.05$; irinotekan ile tedavi edilen hücrelerle karşılaștırıldı ğında).

The avoiding apoptosis is a characteristic feature of cancer cells. Therefore, detection of apoptosis and 
targeting genes in apoptotic signal transduction pathways is an experimental tool not only in drug discovery but also in clinical trials to confirm drug activity in the development of new anti-cancer treatment approaches (Carneiro and El-Deiry, 2020). The rapamycin mammalian target (mTOR) / AKT pathway is known to be associated with many neoplastic diseases. The activation of this pathway may be the result of mutations in the AKT genes, also known as protein kinase B, or the loss of the phosphatase and tensin homolog (PTEN). Considering the pioneering role of mTOR, Akt and PTEN in the tumorigenesis of cells, it highlights the targeting of these genes in the development of new therapeutic approaches (Ocana et al., 2014). Rahimi et al. (2019) reported that $P$. oleracea hydro-ethanolic extract inhibited viability in U-87 human glioblastoma cancer cells in a time and dose dependent manner and caused inhibition of NF-kB, an important regulator of apoptosis and survival. It has been reported that Portulacerebroside A, isolated from the aerial parts of $P$. oleracea, regulates the mitochondrial death pathway in human liver cancer HCCLM3 cells by affecting the activation of p38MAPK and JNK proteins, which have important roles in the regulation of apoptosis (Zheng et al., 2014). The results of present study indicated that POM suppresses proliferation
A

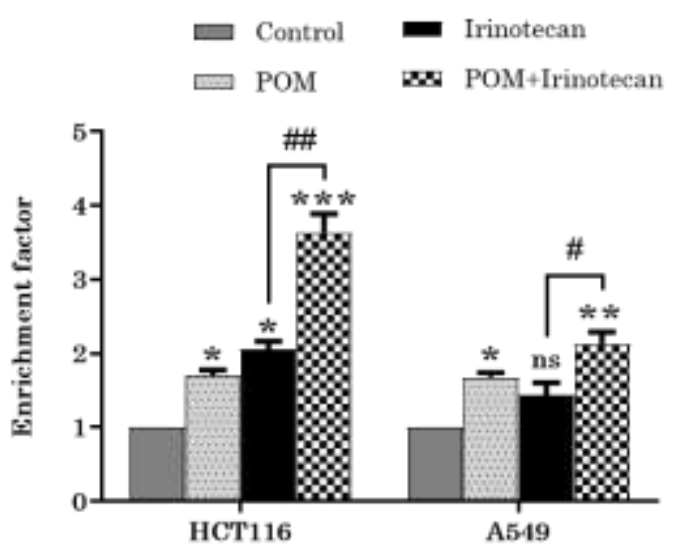

B

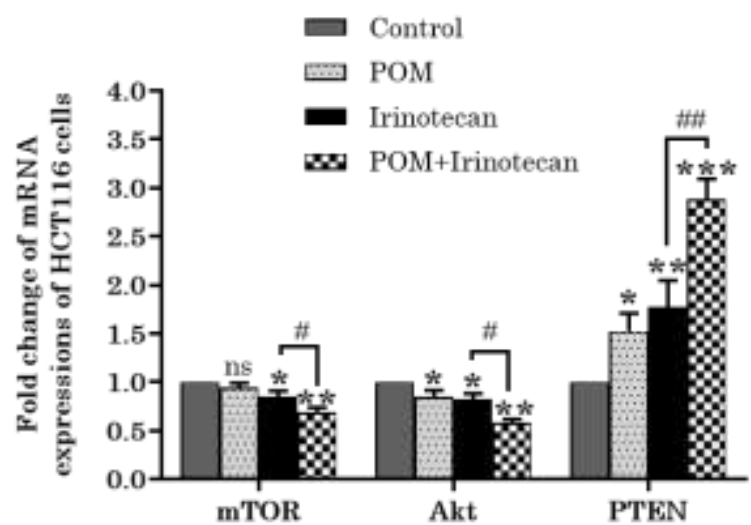

C

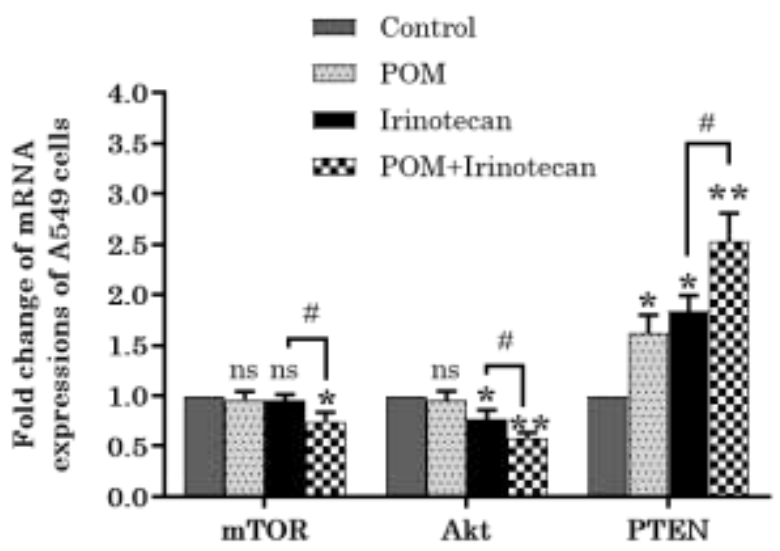

Figure3. (A) Apoptotic effect of P. oleracea methanol extract and / or irinotecan treatments on HCT116 and A549 cells. (B-C) Changes in mTOR, Akt and PTEN mRNA expression levels in HCT116 (B) and A549 (C) cells treated with POM and / or irinotecan. $\left({ }^{*} \mathrm{P}<0.05,{ }^{*} \mathrm{P}<0.01,{ }^{*} * \mathrm{P}<0.0001\right.$; compared with the untreated cells. ${ }^{\#} \mathrm{P}<0.05,{ }^{\#} \mathrm{P}<0.01$; compared with the irinotecan treated cells. ns=not significant).

Şekil 3. (A) P. oleracea metanol ekstraktı ve / veya irinotekan tedavilerinin HCT116 ve A549 hücreleri üzerindeki apoptotik etkisi. (B-C) POM ve / veya irinotekan ile tedavi edilen HCT116 (B) ve A549 (C) hücrelerinde mTOR, Akt ve PTEN mRNA ekspresyon seviyelerindeki değişiklikler. $(* P<0.05, * * P<0.01, * * * P<0.0001$; tedavi edilmeyen hücrelerle karşılaştırıldığında. ${ }^{\#} P<0.05$, ${ }^{\# P<0.01 ; ~ i r i n o t e k a n ~ i l e ~ t e d a v i ~ e d i l e n ~ h u ̈ c r e l e r l e ~}$ karşılaştırıldı ğında. $n_{s}=$ farklılık anlamlı değgil).

in a dose-dependent manner on different cancer cell lines, HCT116 and A549, and enhances the regulatory effect of irinotecan on mTOR, Akt and PTEN genes in important apoptotic and survival pathways, in 
accordance with these studies. Figure $3 \mathrm{~A}$ shows the effect of POM and/or irinotecan treatments on apoptosis, while Figure $3 \mathrm{~B}$ and $3 \mathrm{C}$ shows the change in mTOR, Akt and PTEN gene levels, which have important functions in apoptosis and survival pathways.

These findings suggest that the antiproliferative, anticolony forming and apoptotic effect of POM, particularly its combination with irinotecan, on colorectal and lung cancer cell lines is due to its ability to modulate the mTOR, Akt and PTEN pathway genes.

\section{CONCLUSION}

In conclusion, the combined treatment of methanolic extract of $P$. oleracea and irinotecan has a synergistic effect compared to their single use in inhibiting proliferation of HCT116 colorectal cancer and A549 lung cancer cells, inducing apoptosis by modifying the expression of the mTOR, Akt and PTEN. Therefore, the combination of $P$. oleracea and irinotecan has the potential to be a good approach in inducing cell death in colorectal and lung carcinogenesis. Advanced molecular mechanistic studies on $P$. oleracea may pave the way for new therapeutic combination therapies to be used in colon and lung cancer treatment.

\section{ACKNOWLEDGEMENTS}

The author would like to thank Mr. Yakup Yapar from Faculty of Arts and Sciences, Department of Biology, Bingol University for his kindly efforts in the identification of the plant samples and in the creation of herbarium records.

\section{Contribution Rate Declaration Summary}

The authors declare that they have contributed equally to the article.

\section{Conflicts of Interest Statement}

The authors declare that no conflict of interests.

\section{REFERENCES}

Afolayan FI, Sulaiman KA, Okunade WT 2020. Ethnobotanical survey of plants used in cancer therapy in Iwo and Ibadan, South-Western of Nigeria. Journal of Pharmacy \& Pharmacognosy Research 8(5): 346-367.

Aizpurua- Olaizola O, Ormazabal M, Vallejo A, Olivares M, Navarro P, Etxebarria N, Usobiaga A 2015. Optimization of supercritical fluid consecutive extractions of fatty acids and polyphenols from Vitis vinifera grape wastes. Journal of Food Science 80(1): 101-107.

Al-Sheddi ES, Farshori NN, Al-Oqail MM, Musarrat J, Al-Khedhairy AA, Siddiqui MA 2015. Portulaca oleracea seed oil exerts cytotoxic effects on human liver cancer (HepG2) and human lung cancer (A-
549) cell lines. Asian Pac J Cancer Prev 16(8): 33833387.

Borah P, Banik BK 2020. Medicinal plants and their compounds with anticancer properties. In Green Approaches in Medicinal Chemistry for Sustainable Drug Design 759-776.

Bray F, Ferlay J, Soerjomataram I, Siegel RL, Torre LA, Jemal A 2018. Global cancer statistics 2018: GLOBOCAN estimates of incidence and mortality worldwide for 36 cancers in 185 countries. CA: A Cancer Journal for Clinicians 68(6): 394-424.

Carneiro BA, El-Deiry WS 2020. Targeting apoptosis in cancer therapy. Nature Reviews Clinical Oncology 17(7): 395-417.

Chou TC, Talalay P 1984. Quantitative analysis of dose-effect relationships: the combined effects of multiple drugs or enzyme inhibitors. Advances in Enzyme Regulation 22: 27-55.

El-burai H, Alzaharna M, Isleem R, El-Hindi M, Sharif F 2020. Anticancer activity of Rosemary (Rosmarinus officinalis L.) and Oats (Avena sativa L.) Extracts, and their antitumor enhancement of 5Fluorouracil on Colon Cancer Caco-2 Cell Line. International Journal of Herbal Medicine 8(3): 138146.

Erdogan MK, Agca CA, Askın H 2020b. Achillea biebersteinii extracts suppress angiogenesis and enhance sensitivity to 5-fluorouracil of human colon cancer cells via the PTEN/AKT/mTOR pathway in vitro. Asian Pacific Journal of Tropical Biomedicine 10(11): 505-515.

Erdogan MK, Agca CA, Askin H 2019. Enhanced antiproliferative and apoptotic effects of 5fluorouracil by combined with Pistacia eurycarpa Extracts on human colorectal cancer cells. Biological Diversity and Conservation 12(1): 27-38.

Erdogan MK, Gecibesler İH, Behcet L 2020a. Chemical constituents, antioxidant, antiproliferative and apoptotic effects of a new endemic Boraginaceae species: Paracaryum bingoelianum. Results in Chemistry 2: 100032 .

Ferreira CG, Epping M, Kruyt FA, Giaccone G 2002. Apoptosis: target of cancer therapy. Clinical Cancer Research 8(7): 2024-2034.

Franken NA, Rodermond HM, Stap J, Haveman J, Van Bree C 2006. Clonogenic assay of cells in vitro. Nature Protocols 1(5): 2315-2319.

Gecibesler IH, Erdogan M 2019. A new nutraceutical resource from a rare native plant growing in Turkey and for its spectro-chemical and biological insights: Endemic Diplotaenia bingolensis (Apiaceae). Spectrochimica Acta Part A: Molecular and Biomolecular Spectroscopy 223: 117358.

Huang H, Wang X, Zhang X, Zhang G, Jinbo M, Wang H, Jiang W 2020. Ganciclovir reduces irinotecaninduced intestinal toxicity by inhibiting NLRP3 activation. Cancer Chemotherapy and Pharmacology 85(1): 195-204. 
Jayathilake AG, Kadife E, Luwor RB, Nurgali K, Su $\mathrm{XQ}$ 2019. Krill oil extract suppresses the proliferation of colorectal cancer cells through activation of caspase 3/9. Nutrition \& Metabolism 16(1): 1-15.

Li J, Wang R, Kong Y, Broman MM, Carlock C, Chen L, Liu X 2017. Targeting Plk1 to Enhance Efficacy of Olaparib in Castration-Resistant Prostate Cancer. Molecular Cancer Therapeutics 16(3): 469479.

Lim YY, Quah EP 2007. Antioxidant properties of different cultivars of Portulaca oleracea. Food chemistry 103(3): 734-740.

Livak KJ, Schmittgen TD 2001. Analysis of relative gene expression data using real-time quantitative PCR and the 2- $\triangle \triangle \mathrm{CT}$ method. Methods 25(4): 402408.

Luzhetskyy A, Pelzer S, Bechthold A 2007. The future of natural products as a source of new antibiotics. Current opinion in investigational drugs (London, England: 2000) 8(8): 608-613.

Majolo F, Delwing LKDOB, Marmitt DJ, BustamanteFilho IC, Goettert MI 2019. Medicinal plants and bioactive natural compounds for cancer treatment: Important advances for drug discovery. Phytochemistry Letters 31: 196-207.

Mali PY 2015. Assessment of cytotoxicity of Portulaca oleracea Linn. against human colon adenocarcinoma and vero cell line. Ayu 36(4): 432436.

Nemzer B, Al-Taher F, Abshiru N 2020. Phytochemical composition and nutritional value of different plant parts in two cultivated and wild purslane (Portulaca oleracea L.) genotypes. Food Chemistry 126(621): 1-9.

Newman DJ, Cragg GM 2016. Natural products as sources of new drugs from 1981 to 2014. Journal of natural products 79(3): 629-661.

Ocana A, Vera-Badillo F, Al-Mubarak M, Templeton AJ, Corrales-Sanchez V, Diez-Gonzalez L, Amir E
2014. Activation of the PI3K/mTOR/AKT pathway and survival in solid tumors: systematic review and meta-analysis. PloS One 9(4): 195-219.

Ojima I 2008. Modern natural products chemistry and drug discovery. Journal of medicinal chemistry 51(9): 2587-2588.

Payudara S, Dan Nasofarinks K, Tan G, Wong K, Pearle-Wong GQ, Yeo S, Hueh ZAN 2013. In vitro Cytotoxic and antiproliferative effects of Portulaca oleracea methanol extract on breast, cervical, colon and nasopharyngeal cancerous cell lines. Sains Malays 42: 927-35.

Rahimi VB, Mousavi SH, Haghighi S, Soheili-Far S, Askari VR 2019. Cytotoxicity and apoptogenic properties of the standardized extract of Portulaca oleracea on glioblastoma multiforme cancer cell line (U-87): a mechanistic study. EXCLI Journal 18: 165-172.

Rajesh E, Sankari LS, Malathi L, Krupaa JR 2015. Naturally occurring products in cancer therapy. Journal of Pharmacy \& Bioallied Sciences 7(Suppl 1): $181-183$.

Xiang L, Xing D, Wang W, Wang R, Ding Y, Du L 2005. Alkaloids from Portulaca oleracea L. Phytochemistry 66(21): 2595-2601.

Younes M, Ammoury C, Haykal T, Nasr L, Sarkis R, Rizk S 2020. The selective anti-proliferative and pro-apoptotic effect of A. cherimola on MDA-MB231 breast cancer cell line. BMC Complementary Medicine and Therapies 20(1): 1-10.

Zheng GY, Qu LP, Yue XQ, Gu W, Zhang H, Xin HL 2014. Portulacerebroside A induces apoptosis via activation of the mitochondrial death pathway in human liver cancer HCCLM3 cells. Phytochemistry Letters 7: 77-84.

Zhou YX, Xin HL, Rahman K, Wang SJ, Peng C, Zhang H 2015. Portulaca oleracea L.: a review of phytochemistry and pharmacological effects. BioMed Research International 925631: 1-11. 